\title{
The experience of adults who were "unschooled" during their youth: A phenomenological approach
}

\author{
Joëlle Gaudreau, Christine Brabant
}

Abstract: To better understand the experience of unschooling, non-directive in-depth interviews with five Quebec adults who had experienced it were conducted according to a phenomenological approach, revealing their perceptions of their educational experiences and their families, as well as their views of the world. Certain aspects of the testimonies corroborate the results of previous studies concerning self-directed learning, use of information technology, development of interests, and participation in a support group; others reveal limits when it comes to learning perseverance, pursuit of complex learning goals, school integration, and evaluation. The participants also spoke of family conflicts, parental control, negligence, and the influence of this experience on their views of society, work, the school system, and the role of government in education.

Key words: homeschooling, unschooling, phenomenology, Quebec

\section{Introduction}

A growing minority of children and adolescents acquire their basic education outside of school (Kunzman \& Gaither, 2013). In many countries in North America, Europe, Asia, and Oceania, school attendance is not strictly mandatory because parents can choose another form of education for their children, in certain conditions (International Center for Home Education Research, 2020), which opens the door to a variety of educational practices. However, in most studies on the phenomenon, terms such as "homeschool- 
ing" and "home education" encompass very different practices, ranging from teaching dispensed by parents, to remote schooling offered to young people by a public institution, to unschooling (Gaudreau, 2017). It seems necessary to target just one of these practices to better understand it.

Even though the first use of the term unschooling dates back to the last century (Holt, 1977/2016), today ${ }^{1}$, to our knowledge, there are only about twenty scientific studies that deal specifically with unschooling. Conducted between 2006 and 2020 with German, English, Australian, Canadian, United States, and New Zealand participants and a Hong Kong family, these studies focus mainly on the beliefs and values underpinning this view of education; they note the reasons for this parental choice; and they describe the educational practices of the families and their relationships with the school authorities. Only one study examined adults who had experienced unschooling.

In terms of methods, half are single-case studies and qualitative or mixed research design with ten participants or less; the other half of the corpus is made up of research conducted via online questionnaires with convenience samples, analyses of online conversations and interviews, discussion groups, and ethnographic or mixed research design, with more than 10 and fewer than 100 participants, except for a study by Gray and Riley (2013) that numbered 232 respondents. Six studies were master's or doctoral theses. Although very limited, this exploratory corpus of research made it possible to sketch a portrait of this educational phenomenon.

\section{Foundations of unschooling}

Unschooling parents' conception of learning is centred on the intrinsic motivation of the child and on their capacity for self-directed learning (Curtice, 2014; Gray \& Riley, 2015b; Grunzke, 2010; Kirschner, 2008; O'Hare \& Coyne, 2020). Parents adopting this conception perceive rewards, threats, evaluations, and planned sequential teaching as learning disruptors (Curtice, 2014; Kirschner, 2008). They believe that humans are more engaged in their work and more inclined to overcome obstacles if they have set the objectives themselves (Kirschner, 2008). These parents are also convinced that, when the child acquires in-depth knowledge on a subject that interests them and develops skills on their own, all the commitment, work habits, and effort put into attaining this knowledge can then be transferred to an-

$\overline{1}$ At this article's time of submission (April 2021). 
other learning objective (Curtice, 2014). According to Tyson (2019), the autonomy thus developed should be the basis for lifelong learning, advocated by UNESCO.

Unschooling parents consider their children to be the first evaluators of their work (Curtice, 2014; Gray \& Riley, 2013; Kirschner, 2008). They say they accept error and failure, as childhood is perceived as the best time to experience them (Curtice, 2014). They adopt as a principle respect for the child's learning process (Bertozzi, 2006; Kirschner, 2008). For example, they have no specific expectations as to what age a child should be learning to read (Kirschner, 2008).

Skills development is one of the main educational objectives of these parents, who value the ability to solve problems, with a view to self-actualization, and learning by direct experience, rather than preparation for future life (Kirschner, 2008). They believe that learning takes place at all times, through any experience (Curtice, 2014; Gray \& Riley, 2013; Kirschner, 2008). They value a relinquishing of parental control, joy in family life, connection between parents and children, children's rights, and trust in children (O’Hare \& Coyne, 2020).

Gray and Riley's study (2013) of 232 unschooling families reveals three different conceptions of the parents' role. The first consists in not deliberately attempting to motivate, guide, or direct the child's learning, except if they ask for it - freedom being this educational philosophy's central concept. The second conception involves guiding and motivating the child, by presenting them with resources likely to nurture their centres of interest and by exposing them to different fields of knowledge, potential mentors, or activities (museum visits, concerts, writing or gardening workshops, etc.). Kirschner's study (2008) also identifies this conception of the parents' role. The third conception sees the parents as having educational goals in mind and gently guiding the child, for example, by encouraging them to try a new educational activity every day.

\section{Reasons to choose unschooling}

In the study by Gray and Riley (2013), parents' decision to unschool their children was motivated by observing their educational and emotional experiences, both at school and outside of it (43.5\%); by a philosophy of life that emphasizes freedom and respect for individual differences $(37.1 \%)$; by reflections on their own negative experiences in school, as a student or 
a teacher (31.9\%); and, for a large majority of them, by educational knowledge developed through reading, conferences, websites, and the accounts of other unschooling families' experiences. Certain unschooling mothers thus develop a feeling of self-efficacy that fluctuates according to positive or negative factors in the experience (Morrison, 2016), and a growing confidence in their educational choice (O’Hare \& Coyne, 2020; Riley, 2016).

According to Grunzke (2010) and O'Hare and Coyne (2020), the choice of unschooling is more broadly associated with a critique of mainstream culture, particularly as it applies to children's education, from perinatality on. For many families, unschooling is an extension of the alternative parenting practices associated with attachment parenting, such as giving birth at home or in a birthing centre with a midwife, extended breastfeeding on demand, babywearing, sharing the parents' bed, and elimination communication (Bertozzi, 2006; Curtice, 2014; English, 2014; Grunzke, 2010; Kirschner, 2008). O'Hare's and Coyne's (2020) dialogical analysis of 19 blog posts published by seven unschooling mothers mentions their criticism of school education for allowing only adult-led activities. More generally, the bloggers condemn ageism (or adultism) in the dominant culture, which they saw as discriminating against children (O'Hare \& Coyne, 2020).

The choice is also in keeping with a refusal of school schedules, seen as overloaded (Gray \& Riley, 2013; Grunzke, 2010; Kirschner, 2008). These parents want to offer the child another way of life that respects their natural sleep cycles (Curtice, 2014; Grunzke, 2010). They also express a resistance to the effects of neoliberalism on school systems, such as results-oriented management and the increased school time, reduced study programs, and multiplied standardized tests it entails (Curtice, 2014; Gray \& Riley, 2013; Grunzke, 2010; Kirschner, 2008; Siconolfi, 2010).

\section{Educational practices and outcomes}

Even though the parents and unschooling's defenders emphasize childhood learning, the studies conducted up to now focus more on parenting practices. In Kirschner's study (2008), the 22 families make efforts to organize their homes in ways that facilitate their children's free exploration and autonomy, whether it is their closets, the refrigerator, or the way art supplies, books, toys, tools, cleaning products, etc. are stored.

The use of new information technology also plays an important role in access to knowledge and even in the growth of this educational movement. 
Though some parents fear cyberaddiction, they appreciate the access to specialized concepts, tutorials, and training of all kinds (Bertozzi, 2006; Curtice, 2014; Siconolfi, 2010). In Curtice (2014), conducted with ten unschooling families, the use of technology by children was assessed using questionnaires and interviews, but also software that tracked children's activity on the computer. It was found that the children spent eight to 10 hours a day on the new technology: they used social networks; did Internet searches; watched videos; read articles and e-books; wrote blogs, forums, and fiction; played and created video games, etc. Online training resources were sometimes used; however, video games represented $90 \%$ of total computer use. In her study of five families, Bertozzi (2006) found that there was no consensus among parents over the attitude they should adopt toward such technology.

In social terms, unschooling parents sought to gradually integrate the child into extended family life and the community. From the start, many unschooling families practice babywearing, which gives babies easier access to the adult world (Kirschner, 2008). Later on, the parents become mediators between the children and community resources likely to nurture their passions (e.g., libraries, nature centres, museums), or give them authentic experiences (Kirschner, 2008). Parents also organize outings with other families, via a support group, or partake in the activities of a resource centre for homeschooled children (Bertozzi, 2006; Kirschner, 2008). In most cases, the child is free to take the courses they want, such as training offered by community organizations, school-type programs organized by homeschooling groups one or two days a week, or sports and art classes. Even in these cases, the parents still consider their child to be unschooled because the activity meets their demand (Curtice, 2014). A mobilization of the extended family is also characteristic of the dynamic in these families, which shows the desire for multiage socialization (Curtice, 2014; Kirschner, 2008). After that, i.e., from the beginning of adolescence, parents no longer play such an active role in searching out resources, and become advisors (Kirschner, 2008). The older the children get, the more the parents leave them alone to seek out their own opportunities to make friends or find mentors based on shared interests, and to explore educational and experiential possibilities in their local community and the world outside (Curtice, 2014; Gray \& Riley, 2015b; Kirschner, 2008).

Furthermore, where education in cultural diversity and social justice are concerned, the practice of the 94 unschooling parents recruited by Morrison (2018) largely mirrors that of public schools in the United States, generally summarized by a reliance on the child's exposure to diversity, 
without too much importance ascribed to discussion or analysis of issues of inequality or exclusion, and even less to social action. From this, Morrison deduces that, because the unschooling is inherently child focused and resistant to any planning or imposition, "unschooling might be philosophically incompatible with a purposeful social justice/multicultural education" (p. 109).

To our knowledge, only one exploratory study looked at the academic performance of unschoolers specifically. Out of a sample of 37 homeschooled Canadian children aged five to ten, 25 were offered structured homeschooling, and 12 were offered unstructured homeschooling, that is, their mothers considered themselves to be unschoolers (Martin-Chang \& al., 2011). A third group of children attended public school. The results indicated that the children in the first group scored higher on standardized tests than those who attended a public school (Martin-Chang $\&$ al., 2011). An exploratory analysis (given their small number) of the results of the unschooled children revealed that they had scored the lowest of the three groups (Martin-Chang \& al., 2011).

In Riley's study (2018), 28 unschooled adults completed an online questionnaire to explain how and when they learned to read. All participants recalled being read to by their parents every day as a child. Thirteen indicated that learning to read seemed to have happened naturally for them, with little to no teaching. For nine of the participants, learning was facilitated by a family member with, for example, workbooks, flashcards, or games. For three of the participants, reading was a struggle and not an intrinsic interest. The age at which they learned to read was under five years for four participants, between five and seven for 14 participants, between seven and eight for five participants, and over eight for two participants; one reported learning to read in their early teens. Two respondents could not recall the age at which they learned to read (Riley, 2018).

\section{The monitoring of unschooling}

Dhouib's study (2019) asked Quebec unschooling parents how much monitoring of their educational practices by the school authorities they thought desirable, taking into account the right of children to education. In discussion sessions in subgroups, the 25 parents weighed three approaches: an absence of interaction, an offer of support to the families, and an assessment of the child's educational experience. Depending on the parents' proposal, this assessment might concern either the educational environment 
being offered to the child, or their educational path, and would be fulfilled by examining a portfolio, having an informal discussion with the family, or visiting the home. Dhouib (2019) examined all of the approaches proposed with an evaluation grid relating to the right of children to education, composed of five conditions for respecting this right and their indicators: the third approach satisfied all criteria. This easing of the school-family relationship in an unschooling context is backed by Riley's study (2016), which reports that Hong Kong authorities, very rarely confronted with homeschooling or unschooling, gradually came to look on an unschooling parent couple as exemplary parents.

\section{Adults who have experienced unschooling}

In a second study by Gray and Riley (2015a, 2015b), 75 adult participants from the ages of 18 to 49 completed an online questionnaire on their perceptions of their educational experience, and their likelihood to take up higher education, find a satisfactory job, and have a fulfilling social life. Of the 75 , 24 never went to school, 27 left after sixth grade, and 24 did some schooling after sixth grade, but not in the last two years of high school.

The results indicate that $83 \%$ of respondents (62) attended a post-secondary school. Of those, at the time of the survey, 33 were in undergraduate studies or had an undergraduate degree; 13 were in postgraduate studies or had a postgraduate degree; 29 had taken another kind of post-secondary studies (e.g., cooking, business administration, massage therapy, or sign language interpretation). Half of the participants who had attended university (23 out of 46) reported advantages relating to their unschooling: not being worn down by prior schooling, the self-direction they had learned, the awareness of their freedom of choice, and their determination to get as much as the educational institution had to offer. Seven participants mentioned having difficulties adapting to the formality of the courses, which were quickly overcome without impeding their progress. Only three participants considered themselves to be at a disadvantage with students who had been attending school the whole time.

In terms of employment, $77 \%$ of respondents saw a clear link between their current jobs and the centres of interest developed during their period of unschooling: $48 \%$ of participants were pursuing a career in the arts, $53 \%$ were entrepreneurs, and $29 \%$ worked in social or natural sciences, technology, engineering, or mathematics. 
The participants note unschooling's positive repercussions in their lives: their capacities for self-determination and self-motivation (75\%); a strong sense of responsibility (48\%); a continued interest in learning (44\%); selfconfidence $(43 \%)$; an easier transition to adult life $(33 \%)$; the absence of school-related stress factors $(28 \%)$; and more time spent with the family (24\%). In terms of drawbacks, 28 respondents $(37 \%)$ identified none. The other 47 mentioned receiving unschooling-related critiques and judgments (28\%); a certain isolation, particularly if there were few unschooled children in their area (21\%); and, for three of them, major deficits in terms of learning (11\%). These last three said they had experienced parental negligence or forced isolation, not having been free to attend school if they wanted to. They attributed their situation either to a mother's mental disorders, a father's lack of involvement, or parents' fundamentalist Christian beliefs. That said, most respondents considered that the advantages outweighed the disadvantages.

In short, the rare studies on unschooling provide an understanding of its foundations, the reasons for the parents' choice and educational practices, and the monitoring methods they deem acceptable. It is clear that the research examines the parents above all; it only enlists the young people involved to observe them or ask them to name their activities. Gray and Riley $(2015 a, 2015 b)$ are the only researchers to have investigated adults who had experienced unschooling in their childhood, to know, via an online questionnaire, their situations and their assessments of their educational experience. However, to our knowledge, no study has given them a platform to freely explain their experiences, in order to better understand them.

\section{Question and research objectives}

This study asked the following question: what meaning do adults who have been unschooled give to their educational experience? The objectives pursued were to: 1) describe their points of view of their educational experience and the path they took; 2) better understand the experience of unschooling from this point of view.

\section{Methodology}

For this exploratory study, five Quebec adults who had experienced unschooling were recruited to share their point of view in in-depth interviews, conducted and analyzed according to the phenomenological approach. 


\section{Phenomenological approach}

Phenomenology examines the original mode of manifestation of phenomena, i.e., consciousness, defined as the means of access to all that occurs in experience, because one cannot relate to anything without consciousness's assistance, and nothing can be said without implicitly including it (Bordeleau, 2005; Giorgi, 1997). This implies that any analysis of the world supposes a subject for which the world is (Bordeleau, 2005; Giorgi, 1997). This epistemological perspective is important in human sciences because it can be used to go beyond the Cartesian and dualist ontological understanding of the subject-object relationship, which sees the subject and object as two independent entities that must be linked by science (Giorgi, 1997; Meyor, 2005).

To be considered phenomenological, research must include the use of a reduction method (Bordeleau, 2005; Giorgi, 1997). Phenomenological reduction is a process that requires abstaining from taking the world for granted, not immediately agreeing to say that an object, understood in its most general possible extension, "is," but seeking instead to understand what makes a being say that an object "is" (Bordeleau, 2005; Creswell, 2013; De Monticelli, 2000; Giorgi, 1997). It involves returning to the thing itself, as it is manifested in consciousness, emphasizing, in this way, the experiential data (Boutin, 2011). The second requirement of phenomenological reduction is to "put oneself between parentheses," that is, to avoid, insofar as possible, having the researcher's knowledge, prejudices, biases, and theoretical and ideological references intervene in the data collection and analysis phases (Boutin, 2011; Creswell, 2013; De Monticelli, 2000; Giorgi, 1997; Paillé \& Mucchielli, 2012). In this way, the phenomenon can be faithfully described, as it is rendered by the subject or subjects lending themselves to the study.

In short, phenomenology is the systematic investigation of subjective experience, i.e., an analysis of the meaning that individuals assign to a phenomenon (the what), while taking into account the modalities, tonalities, and subjective styles inherent in experiencing this phenomenon (the how) (Boutin, 2011; Meyor, 2005). Ultimately, the phenomenological approach is aimed at describing what individuals have in common in their experience of a given phenomenon (Creswell, 2013).

\section{Participants}

Participant recruiting targeted any adult who had experienced unschool- 
ing for at least four years between the ages of six and 16, lived in Quebec, was able to express themselves in French, and was not the brother or sister of another participant. In May 2016, a letter of invitation to participate in the research project was sent to potential participants known to the student-researcher and to heads of Quebec organizations likely to have been associated with such people (parents' associations and support groups), so that they could forward it to their members. The letter was also published in various relevant groups on the Facebook social network, i.e., groups relating to alternative education and parenting.

When interested people communicated with the student-researcher, she forwarded to them the following definition of unschooling, adapted from those of Gray and Riley (2013) and Holt and Farenga (1981/2003):

Unschooling is not schooling. Children and adolescents experiencing this educational alternative are not made to go to school or to perform school-type tasks at home. More specifically, they are not given an established curriculum, assignments, or tests to measure their progress. Instead, they are allowed the freedom to pursue their own interests and to learn in their own way. However, this does not mean that they eschew classes in the traditional form or refrain from using material associated with the official curriculum if that is their choice.

If they identified with the description, they were sent the information and consent form to participate in the study. Five participants from four administrative regions of Quebec were recruited in this way. Table 1 provides a brief introduction, with fictitious first names. Their experience of unschooling is situated in childhood, adolescence, or both of these periods. There were four women and a man who, at the time of the interviews, were 18 (two of them), 19, 34, and 41. The average duration of the interviews was one hour and thirty minutes.

Table 1 Characteristics of the participants

\begin{tabular}{|l|l|l|l|l|l|}
\hline $\begin{array}{l}\text { Fictitious } \\
\text { first name }\end{array}$ & $\begin{array}{l}\text { Duration of } \\
\text { unschooling }\end{array}$ & $\begin{array}{l}\text { Experienced } \\
\text { unschooling }\end{array}$ & Gender & $\begin{array}{l}\text { Age at time } \\
\text { of interview }\end{array}$ & $\begin{array}{l}\text { Duration } \\
\text { of interview }\end{array}$ \\
\hline Magalie & 11 years & From ages 6 to 16 & Female & 18 & $1 \mathrm{hr} 05 \mathrm{~min}$ \\
\hline Ariane & 5 years & From ages 12 to 16 & Female & 41 & $1 \mathrm{hr} 35 \mathrm{~min}$ \\
\hline Raphaëlle & 5 years & $\begin{array}{l}\text { From ages } 10 \text { to } 11 \\
\text { and } 13 \text { to } 16\end{array}$ & Female & 18 & $1 \mathrm{hr} 09 \mathrm{~min}$ \\
\hline Dominique & 5 years & From ages 12 to 16 & Female & 34 & $2 \mathrm{hrs} 09 \mathrm{~min}$ \\
\hline Frédéric & 4 years & From ages 13 to 16 & Male & 19 & $2 \mathrm{hrs} 09 \mathrm{~min}$ \\
\hline
\end{tabular}

Data collection and analysis 
The method used corresponds to the steps suggested by Giorgi (1997): 1 - conducting non-directive interviews (audiovisual recording), transcribed in full; 2 - listening to the recordings and reading the transcriptions twice, to absorb the data; 3 - segmenting the data into units of meaning (Fig. 1); 4 - grouping the units thematically (using QRS NVIVO qualitative data analysis software) (Fig. 2); 5 - writing an account of each participant's testimony (Fig. 3); 6 - synthesizing the accounts to highlight common aspects.

Following Boutin (2011), in the interviews, the student-researcher proposed the theme via the opening question: "Can you describe your experience of unschooling?," then let the participant express themselves freely, only facilitating the interview by asking for clarifications and reformulating what was said. After the interviews, an email exchange took place with each in order to clarify or validate certain passages in the accounts.

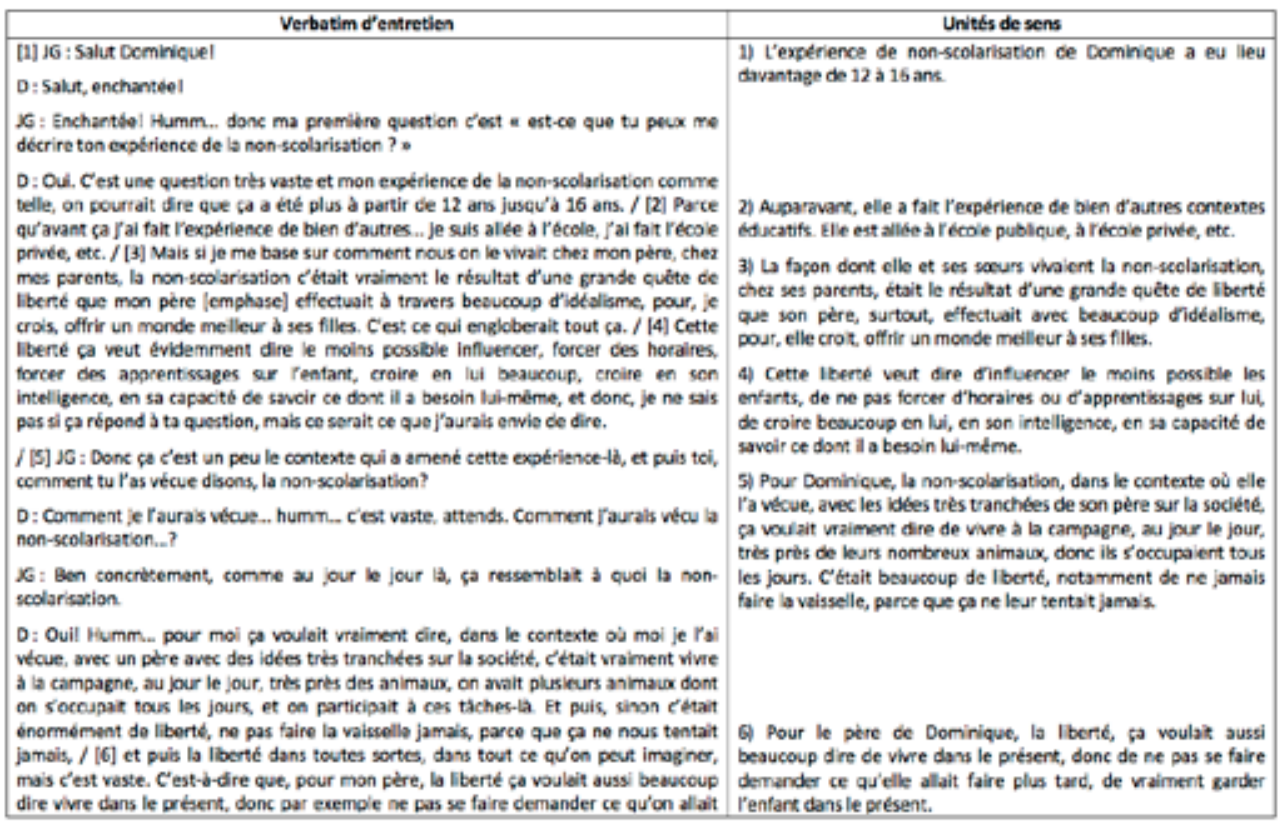

Figure 1: Example of how the data were segmented into units of meaning ${ }^{2}$

2 To maintain participants' anonymity, they were given fictitious first names. 


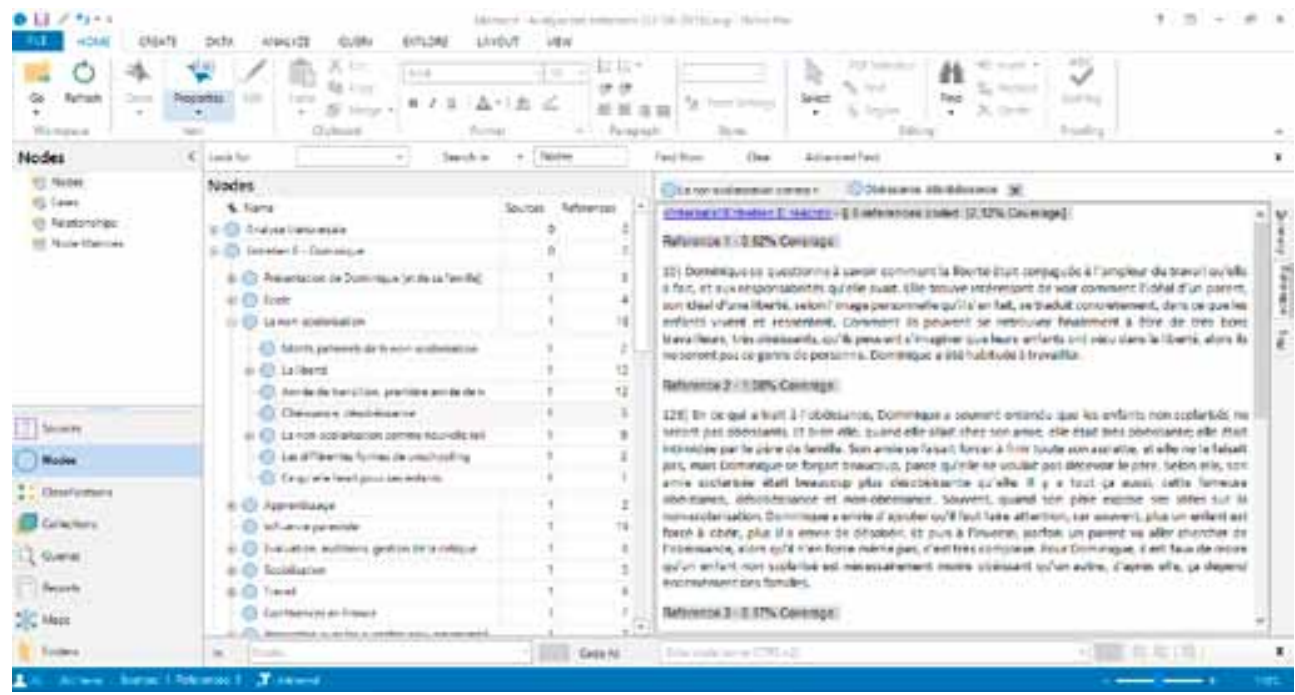

Figure 2: Example of how the units of meaning were grouped thematically

\section{Magalie n'est jamais allée à l'éeole}

Magalie n'est jamais allée à l'école (28). Elle a toutefois pu observer de nombreux jeunes scolarisés au cours de sa vie, notamment pendant les eamps d'été, et elle a constaté que la plupart n'avaient pas de plaisir à l'école; c'est rare qu'ils avaient hilte que l'tete finisse pour y retoumer $(47,48)$. Ce qu'elle trouve le plus dommage par rapport à l'école, c'est le fait que plusieurs jeunes soient écorurés des mathématiques ou de l'histoire, parce que l'apprentissage devient une thebe pour cux, notamment pour ceux ayant des difficultés $(3,47 \ldots, 48)$. Selon Magalie, quand on n'est pas forcé d'apprendre quelque chose pendant six ans, on I'apprície davantage. Par exemple, elle adore I'histoire; souvent quand elle était petite, elle et sa famille allaient visiter des sites historiques, et ses frères se tannaient alors sa mère partait avec cux, mais elle restait pour lire toutes les affiches racontant l'histoire des lieux (..,47).

Selon Magalie, comme pour toute chose, il n'y a pas que des mauvais cótés à l'école (49...). Sa scrur a quelques fois envisage d'y aller, parce qu'elle aime beaucoup le côé social y étant attaché. Finalement, elle ne l'a pas fait; la scuur de Magalie est un peu hypersensible, et elle a quelques difficultés de concentration, alors elle croyait que ce serait difficile pour elle d'aller à l'école. Magalie, quant à elle, n'a jamais vraiment eu envie d'y aller. Quand elle était plus jeune, elle se disait qu'elle aimerait peut-être aller en secondaire 5 pour passer les examens et voir ce que c'était, mais entre-temps, ses passions et ses projets ont change (...49). Magalie a deja refflechi à la possibilité d'aller au cégep, mais elle ne croit pas qu'elle puisse y apprendre beaucoup de choses en lien avee les sujets qui l'intéressent, soit l'entrainement des

Figure 3: Excerpt of an account from a participant's testimony 


\section{Results}

After a brief description of the educational context and the path each participant took, drawn from the account ${ }^{3}$ of their testimony, common aspects of their experience, obtained by the analysis described in 2.3 , are presented.

\section{Learning contexts and paths}

Magalie lives in a family of several children. She is still living in the family home, in the country, where her family runs a riding centre. Unschooled from the ages of six to 16 , she never went to school. She never experienced evaluations because she was not registered with the school authorities. She travelled extensively with her family. Her mother was more present than her father in her education. Magalie has been fascinated by horses since her earliest childhood; she wants to open a refuge for wounded animals. Since the age of 15, she has been managing a small stable with a few horses, which takes up some ten hours of paid work per week. She also trims horse hooves for clients living nearby.

Ariane lived with her father and stepmother on a small farm. She grew up in a religious community that she describes as sectarian, attending religious congregations for over 12 hours per week. From kindergarten to sixth grade, she was at the top of her class and was classified as gifted in high school. A change in the parental custody agreement, followed by a move, enabled her father to take her out of school for religious reasons since the school authorities in their new territory of residence were unaware of their presence. Ariane assumed her education alone via school notebooks and clandestine correspondence courses. According to the Quebec legal framework, she had to be 16 to take the courses, but she lied on her registration form, and was able to take them for a time until she was discovered. At 16, Ariane passed her exams to obtain a high school diploma. Since then, she has completed a bachelor's degree in literature and a master's in education and now works in education.

Raphaëlle lives with her mother in a blended family with a number of children. Her mother is in favour of unschooling, while her father would have preferred a more conventional educational path. She went to school intermittently: first in kindergarten and first grade, then three days in second grade; then, in sixth grade, then two days in high school. Her depar-

\footnotetext{
3 The full accounts can be consulted in Gaudreau's thesis (2017).
} 
tures from school were due to difficult relationships with her teachers and her placement in a special education class in high school, where she felt ill at ease. Raphaëlle had difficulties with mathematics and paying attention, particularly in situations where she was being evaluated. At home, she experienced a gradual transition from homeschooling to unschooling. She worked in a grocery store and then as a waitress. She has wanted to become a midwife since assisting her mother when her little brother was born; she had begun an online birth support training when she was interviewed.

Dominique is the oldest in her family; two of her siblings have never gone to school. In her childhood, her family lived on a small farm in the country. She went to kindergarten, then had difficulties adapting in first grade, and her father agreed to let her quit school. She was homeschooled under school supervision in the first and second grades. In the third grade, she attended a school based on an alternative pedagogy in another Canadian province. Then, in fourth grade, a person close to the family organized a "one-room school" for Dominique and a few other children. This person then founded an alternative school in another province, which Dominique attended in the fifth and sixth grades. When she returned to her parents', her father was ideologically highly unfavourable toward high school, which he considered a prison, so she opted for unschooling. She helped with the farm work and managed a family store from the ages of 13 to 23. Since then, she has worked in various businesses.

Frédéric comes from a large family. He went to kindergarten, then his mother suggested homeschooling and he agreed. His mother was the most involved parent in the experience, which gradually transformed into unschooling. His father had to travel for work, but introduced him to programming. Frédéric met most of his friends through the local support group. At 19, he lived alone in an apartment and worked full time as a programmer, a trade he says he taught himself via websites, tutorials, and online courses, coached by a mentor. At the time of the interview, he was remotely completing the courses necessary to obtain a high school diploma, with the goal of becoming a mechanical engineer.

\section{Educational experiences}

A transversal analysis of the participants' testimonies highlighted their perceptions of their educational experience. First, certain participants said that they only counted on themselves and those close to them to learn. For Dominique, taking a course betrayed the principle of independent learning: 
We understood that, for us to have value in our parents' eyes, especially in my father's eyes, under the gaze of my father, we had to learn by ourselves, that that was what was valued. So much because we heard him telling it to everybody too, so obviously, we were like, "Okay, here, we have to learn by ourselves." (...) so not necessarily to ask to go take a course, do a course on something (...) I put pressure on myself to learn everything on my own.

Others were still able to rely on different persons (professors, mentors, friends) or the Internet. Frédéric strongly emphasized how important it was in his education to have access to the Internet (sites, online courses and tutorials):

That's it, I'm a great autodidact, I've always learned on my own, in books, with the Internet, I'm really happy about being born in this era. (...) So, well really, in the beginning, Wikipedia was my friend [small laugh], but when I was tripping on the Mayans, I was mostly looking for glyph correspondence tables. (...) So it was him that programmed that, and it was him that introduced me to programming, and then I learned it on my own, on the Internet, more things than my father could teach me, so... He started me on that.

Most of the participants mentioned having learned to read at their own pace, sometimes at a relatively late age, like Magalie, who said she read her first book at about the age of 12 :

I really started to read novels, series of novels, I think I was 12 years old. And I remember, when I was young, I think I started to read quite late, because I remember comments from certain people, like, "She isn't reading at her age yet, that's a little late, how is it that she doesn't read?" My mother never wanted to push us to do that because she didn't want to turn us off. And I think I was 12 when I started my first book, which had 12 volumes, and finally I read them all pretty quickly, and after that I started to read a lot.

Everyone except Magalie thinks that autodidacticism has its limits, hitting a ceiling when confronted with the complexity of certain notions. Frédéric thinks engineering, electronics, and medicine are fields best learned in university. Ariane thinks advanced physics and mathematics are too complex to study on her own. In their opinion, relying only on a child's interest and willingness may prevent them from pursuing learning that requires 
sustained effort; they may tend to avoid situations that involve a certain amount of adversity, especially if their parents never encouraged them to persevere in the face of obstacles.

Regarding their perception of their unschooling period, the participants felt that they were living in the present moment, with some dreams and future projects. Any activity was performed to satisfy an immediate need, desire, or request from another person. For example, it was in saving animals that Magalie developed the interest that led her to imagine opening a refuge. Dominique, in working in her father's store and doing tasks on the family farm, responded more to the needs of others and to a desire to prove "her seriousness" or "her efficiency" to others, but she was still living in the immediacy of these demands. Ariane responded to her need to try to continue to be a "good student." For Raphaëlle, "unschooling is to live, it's to do what you want to do every day: cook, swim, garden, buy groceries, etc." As for Frédéric, he found that children who went to school seemed to know more what they wanted to do in the future, while he knew what he wanted to do in the present.

Proximity socialization, with children in the neighbourhood or friends of their parents, was an important element for all participants. They also developed lasting friendships and a feeling of belonging in homeschooling support groups. In general, they appreciate having experienced this multiage socialization. They also experienced a certain social and cultural diversity by spending time with young people who went to school, except for Ariane, for whom the absence of this possibility confined her to a sectarian socialization, she says.

All participants mentioned having felt loneliness for various stretches of their unschooling experience, and even beyond. They all think that solitude is more common among unschooled children than among others. In different ways, they say they suffered from marginalization or stigmatization. Members of their extended family, neighbours, and other young people quizzed them to test their knowledge or made hurtful comments. Many felt different, strange, and even rejected, and these feelings lingered, to a lesser extent, in certain participants at the time of the interview.

\section{Families' decisions and ideologies}

Raphaëlle associates her family life with happiness, while Ariane believes she experienced parental negligence. In retrospect, certain participants con- 
sider that the choice of unschooling was imposed on them, explicitly or implicitly, because their parents disapproved of public schools or didn't have the skills to teach them at home. And even though they admit that the initial impetus might have come from the child themselves, particularly if they didn't appreciate certain aspects of school, three participants (Frédéric, Dominique, and Ariane) wondered how old a child should be before they could decide on the type of education that would be most beneficial to them in the long term.

For Raphaëlle, Frédéric, and Dominique, adopting unschooling was gradual because a period of homeschooling followed their initial withdrawal from school. According to them, a lowering of the parents' discipline level, due to the demands of daily life, and growing confidence in their children's abilities to learn on their own, slid their education to unschooling.

Ariane and Dominique felt parental control strongly, religious for Ariane and political-philosophical for Dominique:

I was formatted to think like my father. Because often I didn't share my father's opinions, but at home, it wasn't very open around the discussion table: it was my father who would tell us how life was going, he would describe to us how horrible society was, and how this and that was, and how school was a prison. But there wasn't a lot of discussion on points of view. (...) even if I would have rather, instead of working in a store, hummm, go to theatre school or do things that were more me, things I was into, that interested me, I would never have dared (...) I was really more brainwashed by my father. (Dominique)

They say they began freeing themselves from their parents' ideologies when they started Cégep ${ }^{4}$ or created a physical distance from their families in their mid-twenties. For Raphaëlle, Magalie, and Frédéric, who are under 20 , parental influence still affects their interests, activities, and professional projects, which are an extension of those of a parent.

The participants appreciated the freedom to explore what interested them, the absence of an imposed schedule, the possibility to move at their whim and to satisfy their primary needs without asking permission (e.g., eating, going to the bathroom), and not being forced to do or learn anything.

\footnotetext{
4 Cégep is a Quebec public college.
} 
However, in the absence of an authority framework, Dominique believes she analyzed the things her parents left unsaid to understand what they prized. According to her, this is what made the children in her family obedient and perfectionists, to the great astonishment of their father, who said he had never imposed that upon them, but was himself very meticulous in his work.

All of the participants experienced parental dissent over their unschooling because only one parent adhered to it entirely. One participant experienced contradictory messages, the discrediting of a parent, and the parents' separation. She said that it then became very difficult to even express a desire to go to school.

\section{Views of the world}

The participants consider that their educational experience coloured their perceptions of the world. Dominique and Ariane were immersed in an intense opposition between the legitimacy of their education mode and a debasement of school education. They believed in it, but both now repudiate it, rejecting this doctrinal conception. According to them, the idea that unschooling children are "pure" is a heavy burden to carry, creating pressure to be "different" to correspond to their parents' ideals, which marginalizes them.

Most of the participants express no reluctance to work for an employer, obey instructions, or integrate into a professional structure. Raphaëlle is the only participant who had trouble holding down a job because she doesn't like being controlled or monitored; she wants to work for herself. At the time of the interviews, four participants were working or taking courses in a field related to an interest that they had developed during their unschooling period. According to them, generally, the fact that they did not have a full education did not harm their professional careers. Only once, a job was denied to Dominique because she didn't have a high school diploma.

Frédéric uses a train analogy to express his view of the school system: outside the train, he can get where he wants to go, but not as quickly as its passengers. If he wants to attend a school to reach a professional objective, the barriers are higher for him than for other people of his age. With Raphaëlle and Dominique, the obstacles to returning to school are fear of evaluation and difficulty handling criticism. As for Magalie, she believes that returning to school would prevent her from developing her passion for horses; how- 
ever, a college program in equine techniques is available. Raphaëlle believes that the school system is inhospitable for a diabetic child like her brother. For Dominique, formalizing the world on paper in an academic framework was very intimidating because she lived in a context in which she was barely aware of the date, her geographical situation, etc.

That being said, the participants understand the utility of the school system, particularly because all families do not have the intellectual, financial, and social capabilities to assume their children's education. However, they have their criticisms. For Ariane:

I think I have a pretty autonomous view of learning, and I realized this because I'm doing a master's in teaching, I did two internships, and ended up teaching in high school, when I had never even set foot in one. And I felt that there was something that bothered me, like [she raises her hand] "Miss, can I ... [imitates a teenager]." For me, to see kids 12 to 16 raising their hands to go pee, I found it incredibly traumatizing. At the same time, I understood that, okay, in a system like this, with 1800 students, if everybody went to the bathroom, there would be no one in class, and then you have no more control, and then you no longer know where they are.

The relevance of evaluations is challenged by Frédéric, Ariane, Dominique, and Raphaëlle. Frédéric suggests putting them off to the age of 14; Ariane believes a kindergarten-style approach is preferable until the age of eight, i.e., free play, and that children ready to take on school-type work can do so at their own pace so they don't lose confidence in their abilities very young; Dominique believes that an absence of evaluation builds connections between children by reducing the possibility of comparisons between them; as for Raphaëlle, she criticizes the stress that evaluations put on young people's lives.

Finally, Dominique and Ariane decry the absence of government monitoring of their education. They don't want anybody to have an experience like theirs. According to them, the government has a duty to ensure that children aren't trapped in the asocial world of their parents. Ariane believes that an intervenor must ensure that the educational context is healthy. And if there is negligence, an intervention should be made, with the parents and not the children. She maintains that if the Department of Youth Protection (DYP) had intervened coercively when she was steeped in her father's religious beliefs, she would have reacted very badly, even if deep down she wanted to 
return to school. She agrees that the government should require parents to have a learning project, but doesn't believe examinations are necessary. As for Frédéric and Raphaëlle, they see evaluations by school authorities and threats of being reported to the DYP as a burden. Raphaëlle's mother used a variety of stratagems to be forgotten by them. Magalie went "under the radar" of the authorities without complaining.

Today, these adults think that it is important to offer families a variety of educational options, and none want unschooling to be banned. Moreover, despite her negative experience, Ariane took her son out of school after a trauma that left him unable to function in that setting, and says that her family is doing much better. She now believes that for families who have the necessary resources, homeschooling can be an option conducive to a child's development.

\section{Discussion}

The contributions of this study to research on unschooling are situated in support, in contradiction, and novelty.

\section{Results supporting previous knowledge}

Some of the results of this research are similar to those of previous work on unschooling: an educational experience driven by the satisfaction of immediate needs or desires; the advantages and limits of autodidacticism; the free use of information technology and its reappraisal; a socialization marked by a feeling of belonging to a support group (Bertozzi, 2006; Curtice, 2014; English, 2014; Gray \& Riley, 2013, 2015a, 2015b; Grunzke, 2010; Kirschner, 2008; Siconolfi, 2010) — but also by solitude and marginalization. As in the study by Gray and Riley (2015b), most participants note a strong connection between centres of interest developed during unschooling and their jobs or current fields of education. Furthermore, the gradual slide of homeschooling to unschooling, and the association of unschooling with a "counter-cultural" lifestyle are consistent with the results of Kirschner (2008), Grunzke (2010) and O'Hare and Coyne (2020). An appreciation of time spent with the family, and the value of freedom are apparent, as in the studies of Gray and Riley $(2013$; 2015a) - but also testimonies of parental negligence and enforced isolation. 
Results in contradiction with previous knowledge

Other results contradict those of previous studies. For example, the idea that the child is more inclined to overcome obstacles on a learning path when they are moved by a response to their own needs and interests (Kirschner, 2008) is challenged by certain study participants, who feel that learning perseverance and pursuing complex learning objectives are not guaranteed by this educational principle. Also, previous research advances that, for families practicing unschooling, error and failure are accepted (Curtice, 2014), young people evaluate their own work (Curtice, 2014; Gray and Riley, 2013; Kirschner, 2008), and this respect for each child's learning process is beneficial (Bertozzi, 2006; Kirschner, 2008). However, according to some of the participants in this study, a lack of familiarization with external evaluation leads to an avoidance reaction to evaluation situations (school exams, job interviews, auditions, driver's licence tests).

Furthermore, the participants all revealed the presence of family conflicts and parental dissent over education, generating tensions that affected them as children. Some even spoke of parental control, which is contrary to Tyson's views (2019) of personal autonomy, which she considers to be favoured by unschooling; it also differs from the studies by O'Hare and Coyne (2020) and Gray and Riley (2013), where unschooling is associated with greater joy and harmony in families. Finally, in the study by Gray and Riley (2015b), the majority of adults who had experienced unschooling started post-secondary technical or university education, and half of those who reached the university level reported advantages relating to their educational experience. In this study, in contrast, the participants reported difficulties in integrating the school system.

These participants testify to a less ideal experience than that reported by parents and young children in previous studies. This difference is probably due to the methodology chosen, which offered adults who had experienced unschooling the possibility to retrospectively describe their experience themselves, giving them a temporal and critical perspective.

\section{New dimensions brought up by this study}

Dimensions unexplored until now emerged from the participants' discourses, including the influence of their unschooling experience on their views of the world. According to them, this form of education positively or negatively influenced, lastingly or not, as the case may be, their views of 
society, work, the school system, and the role of government in education. The participants also discussed the outsized influence their parents had on their educational and professional paths, and relativized the actual degree of freedom given to children. The fact that the interviews were non-directive and analyzed according to a phenomenological approach, without a predetermined theoretical framework, contributed to highlighting these new dimensions of the experience.

In the avenues for future research she proposes, Kirschner (2008) wonders if unschooled kids will embody, once adults, the "counter-cultural" views of their parents. To find out, she suggests a longitudinal study of a broad sample of unschooling families. By using a different design, the present study shows that certain adults have come to distance themselves from their parents' ideals, which they deem radical, and to even deplore the educational choice that was made for them. Those not yet in their twenties seem to adhere, at least in part, to the alternative values and practices of their parents and acknowledge that there is a strong link between their professional projects and what their parents exposed them to.

\section{Limits of this study}

This exploratory study describes the experience of five people, without claiming to be representative. Furthermore, the analysis was conducted by a student-researcher ${ }^{5}$ within the limits of her study program. We also note that four of the five participants experienced four to five years of unschooling in adolescence, including the last two years of high school, for all; the fifth was unschooled for the entire mandatory schooling period. It should be remembered then that the results reflect more the experiences of people who, having attended school in elementary school, pursued and finished their mandatory schooling in unschooling form in adolescence. This study and its results are also delimited by the definition of unschooling used to recruit participants, which necessarily circumscribes the practice in question in this study.

\section{Avenues for future research}

The participants' testimonies describe the profiles of varied unschooling parents (anarchist, religious, green, entrepreneur, etc.), and the experience of the children may differ according to their parent's profiles. In Curtice's study (2014), young people who were using new technology eight to 10

\footnotetext{
5 The first author of this article.
} 
hours a day all had a parent working as an expert in information technology. A diversity within the unschooling movement is also suggested by Grunzke (2010), who recognizes that, in the United States, associations of unschooling families present particularities (African American, Buddhist, the do-ityourself movement, etc.) that might lead to distinct situations, while parents having responded to her online questionnaire were all Caucasians and mostly areligious. For future studies, she recommends distinguishing different profiles of unschooling families, rather than aggregating them, to avoid generalizing the results to the entire population concerned by unschooling and better understand the diverse realities experienced in this population.

Moreover, though there is a limited number of scientific studies that present the experiences of adults who have been unschooled, there are many personal narrative accounts of the experience in the form of books, blogs, audiovisual materials, and articles. Analyzing these voices from the public domain in relation to the results of this study is an interesting avenue for future research.

Finally, to our knowledge, no study addresses the quality of learning achieved by the unschooled population, other than through the perceptions of unschooled adults in this study and those of Riley (2018) and Gray and Riley (2015), and the exploratory analysis of Martin-Chang and al. (2011), which suggests there is a gap between unschooled children and those experiencing more structured forms of education (at home or at school). According to the participants in this study, not all unschooling parents are able to assume the educational role they have given themselves. Some participants hold that the state has a duty to monitor unschooling, although they do not agree on the form. It would be useful to test the monitoring proposals formulated by the unschooling parents in Dhouib's study (2019).

\section{References}

Bertozzi, V. (2006). Unschooling media: Participatory practices among progressive homeschoolers. Master's thesis. Massachusetts Institute of Technology, Cambridge, Massachusetts. https://cmsw.mit.edu/unschooling-media-participatory-practices-among-progressive-homeschoolers/

Bordeleau, L.-P. (2005). Quelle phénoménologie pour quels phénomènes? Recherches qualitatives, 25(1), 103-127.

Boutin, G. (2011). L'entretien de recherche qualitatif. Quebec City: Presses de 1'Université du Québec.

Creswell, J. W. (2013). Qualitative inquiry and research design: Choosing among five approaches. Thousand Oaks, California: SAGE Publications Inc. 
Curtice, B. (2014). Ownschooling: The use of technology in 10 unschooling families. Master's thesis. Arizona State University, Tempe, Arizona. https://repository.asu. edu/attachments/140837/content/Curtice_asu_0010E_14317.pdf

De Monticelli, R. (2000). L'avenir de la phénoménologie. Méditations sur la connaissance personnelle. Paris: Paris Aubier.

Dhouib, B. (2019). Les propositions de suivi de l'apprentissage en famille formulées par des parents-éducateurs québécois privilégiant une approche éducative de type unschooling. Master's thesis. Université de Montréal, Montreal, Quebec. https://papyrus.bib.umontreal.ca/xmlui/handle/1866/23571

English, R. (2014). Too cool for homeschool? Accessing underground unschoolers with Web 2.0. In K. Trimmer, A. Black, \& S. Riddle (eds.), Mainstreams, margins and the spaces In between: New possibilities for education research (pp. 112-124). Londron: Routledge.

Gaudreau, J. (2017). Le point de vue d'adultes québécois ayant vécu l'expérience de la non scolarisation (unschooling) au cours de leur enfance et/ou de leur adolescence : une approche phénoménologique. Master's thesis. Université du Québec à Montréal, Montreal, Quebec. https://archipel.uqam.ca/9624/1/M14842.pdf

Giorgi, A. (1997). De la méthode phénoménologique utilisée comme mode de recherche qualitative en sciences humaines: théorie, pratique et évaluation. In J. Poupart (ed.), La recherche qualitative: enjeux épistémologiques et méthodologiques (pp. 314364). Montreal, Quebec: Gaëtan Morin.

Gray, P., \& Riley, G. (2013). The challenges and benefits of unschooling, According to 232 Families Who Have Chosen that Route. Journal of Unschooling and Alternative Learning, 7(14), 1-27.

Gray, P., \& Riley, G. (2015a). Grown unschoolers' evaluations of their unschooling experiences: Report I on a survey of 75 unschooled adults. Journal of Unschooling and Alternative Learning, 4(2), 8-32.

Gray, P., \& Riley, G. (2015b). Grown unschoolers' evaluations of their unschooling experiences: report ii on a survey of 75 unschooled adults. Journal of Unschooling and Alternative Learning, 4(2), 33-53.

Grunzke, R. (2010). Pedagogues for a New Age: childrearing practices of unschooling parents. Doctoral thesis. University of Florida, Gainesville, Florida.

http://ufdc.ufl.edu/UFE0041535/00001

Holt, J. (1977/2016). Growing without schooling - Issue No. 2. In P. Farenga, \& C. Ricci (eds.), Growing without schooling: The complete collection. Vol. 1, 1977 to 1981 (2016 ed., vol. 1, pp. 12-32). Medford, MA: Holt GWS.

Holt, J., \& Farenga, P. (1981/2003). Teach your own: The John Holt book of homeschooling. Cambridge, Massachusetts: Perseus Publishing.

International Center for Home Education Research. (2020). World Homeschooling Regulations. http://icher.org/world.html

Kirschner, D. (2008). Producing unschoolers: Learning through living in a U.S. education movement. Doctoral thesis. University of Pennsylvania, Philadelphia, Pennsylvania. ttp:/ / repository.upenn.edu/cgi/viewcontent.cgi?article $=8018 \&$ context=dissertations Kunzman, R., \& Gaither, M. (2013). Homeschooling: A comprehensive survey of the research. The Journal of Educational Alternatives, 2(1), 4-59.

Martin-Chang, S., Gould, O. N., \& Meuse, R. E. (2011). The impact of schooling on 
academic achievement: Evidence from homeschooled and traditionally schooled students. Canadian Journal of Behavioural Science, 43(3), 195-202.

Meyor, C. (2005). La phénoménologie dans la méthode scientifique et le problème de la subjectivité. Recherches qualitatives, 25(1), 25-42.

Morrison, K. (2016). "The courage to let them play": Factors influencing and limiting feelings of self-efficacy in unschooling mothers. Journal of Unschooling and Alternative Learning, 10(19), 48-81.

Morrison, K. (2018). Unschooling and social justice/multicultural education: (Un)realized potential. Other Education: The Journal of Educational Alternatives, 7(2), 97-117. O'Hare. A., \& Coyne, J. (2020). Unschooling and the self: A dialogical analysis of unschooling blogs in Australia and New Zealand. Culture \& Psychology, 26(3), 484-499. Paillé, P., \& Mucchielli, A. (2012). L'analyse qualitative en sciences humaines et sociales. Paris: Armand Colin.

Riley, G. (2018). Exploring unschoolers' experiences in learning to read: How reading happens within the Self-Directed learning environment. Journal of Unschooling and Alternative Learning, 12(24), 1-33.

Riley, G. (2016). Unschooling in Hong Kong: A case study. Journal of Unschooling and Alternative Learning, 10(20), 1-15.

Siconolfi, R. (2010). How online learning has opened up the potential for unschooling: A personal narrative. Master's Thesis. Nipissing University, North Bay, Ontario. https://www.learntechlib.org/p/120666/

Tyson, L. S. (2019). Trusting children: Lifelong learning and autonomy within the unschooling movement. Journal of Unschooling and Alternative Learning, 13(25), 23-40.

\section{Authors ${ }^{6}$ :}

Joëlle Gaudreau, Ph.D. Student

Department of Administration and Foundations of Education

PO Box 6128

Centre-ville Station

Université de Montréal

Montréal

Québec

Canada

$\mathrm{H} 3 \mathrm{C} 3 \mathrm{~J} 7$

Email: joelle.gaudreau@umontreal.ca

Christine Brabant, Associate Professor

Department of Administration and Foundations of Education

PO Box 6128

Centre-ville Station

Université de Montréal

Montréal

Québec

Canada

$\mathrm{H} 3 \mathrm{C} 3 \mathrm{~J} 7$

Email: christine.brabant@umontreal.ca

6 The authors thank Jacquie Charlton for translation and linguistic revision. 